УДК: 159.9:378.147:005:37.015.3

DOI: 10.26697/ijes.2019.4.24

\section{Медіаперцептивна комунікація як фактор становлення професіоналізму майбутнього фахівця}

Доцент Костюченко О. B. ${ }^{1}$

${ }^{I}$ Київський наиіональний університет культури $i$ мистеитв, Україна

\section{Резюме \\ Вступ:}

В умовах суспільних змін і трансформацій зростає значущість ефективності професійної діяльності, якісної реалізації потенціалу фахівця.

Одним із факторів становлення професіоналізму майбутнього фахівця $є$ інформування про події та явища навколишнього світу, зокрема професійного, в результаті чого вибудовується суб'єктивне уявлення про особливості майбутньої професії.

Активна перцептивна діяльність реалізується у комплексному багаторівневому рішенні проблем, сприяє проявам критичного мислення, когнітивної гнучкості, креативності, адаптаційній пластичності для збереження рівноваги при взаємодії 3 динамічним соціокультурним середовищем.

Соціально-психологічні явища виникають як відображення (пізнання, переживання та засвоєння) різних форм спілкування, зокрема й медіаперцептивної комунікації.

Феномен повсюдної візуалізації зовнішнього світу, медіапростору, інтернету тощо вимагає від майбутнього фахівця свідомого, адекватного ставлення до цього медіакультурного явища.

Особливостями сприйняття зовнішніх об'єктів, що “нав'язані ззовні”, є: свідомий вибір або уникнення об' єктів, тобто свобода вибору і відповідальність за їх споживання; опосередковане спілкування, “зворотній зв'язок” 3 автором чи авторами, ознайомлення 3 їх відкритими чи прихованими ідеями, репрезентованою реальністю, а не об'єктивно “віддзеркаленою”.

\section{Результати:}

Важливим у становленні професіоналізму майбутнього фахівця $є$ формування та розвиток його повноцінного ставлення до професійного простору, насиченого різномодальними образами, штучними формами, а також до можливості зануритися у штучні візуальні, аудіальні, нюхові, смакові, дотикові світи.

Важливою у цьому контексті $є$ думка В. Моляко (2009) про те, що сприймання безпосередньої реальності є основним каналом контакту суб'єкта зі світом, фундаментом його поточного орієнтування - оцінювання й прогнозування перебування свого “Я” в навколишньому контексті, яка підтверджує важливість таких характеристик сприймання, як адекватність та точність, що впливає на характер взаємодії людини з довкіллям.

Теоретико-методологічною базою дослідження $\epsilon$ питання вибірковості сприймання інформації
(B. Аршавський, Л. Веккер, Н. Гольдштейн, М. Дворяшина, Н. Кудрявцева, О. Лурія й інші) в умовах медіакомунікації (О. Баришполець, О. Вознесенська, О. Голубєва, Г. Мироненко, Л. Найдьонова, Н. Обухова, Н. Череповська та інші), що $€$ властивістю творчого сприймання (В. Моляко, І. Біла, Н. Ваганова, Ю. Гулько, О. Костюченко, Н. Медведєва, Т. Третяк та інші), спрямованого на розв'язання певних завдань професійної діяльності, забезпечуючи орієнтування в конкретній ситуації. У сучасних умовах медіаперцептивної комунікації, яка 3 появою нових мультимедіа і новітніх технологій наразі стала досить поширеною, від фахівця вимагається свідоме орієнтування в інформаційних потоках, ефективне “фільтрування" медіапродукції за змістовою спрямованістю відповідно до внутрішньої потреби особистості для недопущення «поглинання» людини; конструктивно критично сприймати-осмислювати відібрану медіапродукцію за іiі зовнішніми візуальними та змістовими складовими.

\section{Висновки: \\ Вже на рівні сприймання відбувається активна перетворююча діяльність, ініціація перцептивної діяльності, що відображає здатність майбутнього фахівця до ініціативної поведінки, коли він не просто пасивно віддається потоку вражень в окремому акті пізнання професійної дійсності, а й активно спрямовує відчуття на максимальну точність іiі бачення, виявляючи власну здатність до розвитку, вдосконалення та розширення власних уявлень про обрану професію, що не лише визначає, а й зумовлює зміст, побудову i протікання діяльності в цілому.}

\section{Інформація про автора: \\ Костюченко Олена Вікторівна - доктор психологічних наук, доцент, доцент кафедри психології, Київський національний університет культури і мистецтв, Київ, Україна. \\ Наукові інтереси: ресурсні та здоров'язберігаючі психотехнології, психологія управління, психологія художньої творчості, складові творчого і професійного потенціалу особистості; https://orcid.org/0000-0001-7853-2670.}

Автор-Кореспондент:

Костюченко Олена Вікторівна

Email Автора-Кореспондента: g2069544@gmail.com 